\title{
Michal Chabada: Kapitoly z dejín stredovekej filozofie II. Raná latinská scholastika.
}

Bratislava, Univerzita Komenského 2015, 118 s.

Ako naznačuje samotný názov, autor knihy sa vo svojej monografickej štúdii sústredil predovšetkým na tri uvedené európske osobnosti stredovekej filozofie a náboženstva. Domnievame sa, že tento výber odzrkadl'uje zámer autora štúdie doc. Michal Chabada prináša tento rok v poradí už druhý diel ${ }^{1}$ svojej vysokoškolskej učebnice tematicky a chronologicky zameranej na dejiny stredovekej filozofie. Kým v prvej učebnici sa zameral na základné pojmy v stredovekej filozofii a na základné míl'niky v podobe prelomových postáv latinského Západu a krest’anského staroveku, v tejto časti náš pohl'ad sústredí na oblast' zrodu scholastickej filozofie, latinskej vzdelanosti a hlavne na zrod kláštorných škôl, z ktorých sa postupne profilovali najznámejšie vzdelávacie inštitúcie stredoveku - univerzity.

Zrod scholastickej filozofie a latinskej vzdelanosti Chabada približuje dejinnofilozofickým spôsobom, ked' sa snaží približit' aj historické dianie na Západe a poukázat' na dôležitost' vel'kých osobností, ktoré na tomto zrode participovali kvôli šíreniu latinského jazyka a vzdelanosti mimo kraje bývalej Rímskej ríše (Lanfranc, Alkuín a d’alší).

Spolu so zrodom tohto Latinského Západu sa vd'aka učencom začína šírit' aj postupne sa jednotiaca forma výučby, ktorá sa na Západe zastabilizovala v podobe septem artes liberales (sedem slobodných umení). Kým na začiatku - ako správne Chabada poznamenáva - existovali len dva stupne štúdia - schola exterior a schola interior - neskôr sa začína aj vd'aka pribúdajúcim prekladom rodit' štúdium trivia a kvadrivia, čo u niektorých katedrálnych a neskôr kláštorných škôl vyvoláva preferenciu jedného alebo druhého $\mathrm{z}$ nich. S touto otázkou bytostne súvisí aj zrod scholastickej metódy, dialogického spôsobu otázky, ktorá až nápadne pripomína dnešnú verifikáciu v oblasti vedy. Rovnako to bolo aj v oblasti rozdelenia filozofie na jednotlivé jej odbory, kde prevládala dvojaká tradícia: tradícia aristotelovského členenia a tradícia stoického členenia filozofie.

Azda najklasickejším problém tohto obdobia je spor o univerzálie tiahnuci sa naprieč rannou scholastikou až po neskorý stredovek. V skutočnosti tento problém siaha ešte ku Gregorovi z Nyssy a jeho polemike ohl'adom tzv. epinoia s Eudómiom, ktorý asi ako prvý ranokrest’anský myslitel' prišiel s teóriou tzv. „nominalizmu“. Chabada tu v tejto súvislosti popisuje pät' najhlavnejších smerov v otázke všeobecnín - od extrémneho realizmu až po extrémny nominalizmus. Každý

${ }^{1} \mathrm{~K}$ prvému dielu pozri (Nemec 2015). 
z týchto prúdov zastávala niektorá z význačných osobností a argumentovala platónskou alebo aristotelovskou argumentáciou. Variácia názvov týchto prúdov je pomerne vel'ká a môžeme s ňou prakticky súhlasit', aj ked' k alternatívnym názvom extrémnemu nominalizmu sa dá ešte pridat' ešte aj iný - tzv. terminizmus.

Autor d'alej rozoberá najznámejšie kláštorné školy tohto obdobia: Laonskú školu s dvoma predstavitel'mi - Anzelmom z Laonu a jeho žiakom Petrom Abelardom, a na druhej strane kláštornú školu v Le Bec, ktorú najviac preslávil Anzelm z Canterbury a jeho metóda „sola ratione“ zdôrazňujúca hlavne racionálnu argumentáciu. Zároveň tento autor prináša svoj bohatý príspevok do scholastiky hlavne tým, že rozpracúva dôkazy Božej existencie, ktoré sa stanú námetom diskusie pre d'alšie storočia.

Okrem Anzelma je dost' vel'ký priestor venovaný Petrovi Abelardovi, ktorý v značnej miere ovplyvnil budúce diskusie o logických témach (čo je a čo nie je pojem), ale stal sa hlavne zakladatel'om myšlienky náboženského dialógu svojím dielom Dialogus, v ktorom sa otázka pravdy stáva tak povediac súčast'ou platónskeho dialógu.

Publikácia venuje ešte priestor dvom kláštorným školám: škole sv. Viktora a škole v Chartres. Obidve z nich boli v tradícii akceptovanými školami, kde prednášali a vyučovali vel'ké osobnosti podporujúce rozvoj štúdia trivia a quadrivia (škola sv. Viktora) či propagovali aj štúdium prírodných vied (škola zo Chartres). Obe tieto školy priniesli jednak zaujímavé alegorické interpretácie Písma a tradície (myslíme hlavne školu sv. Viktora) a jednak pokračovali v niekol'ko stáročí zabehnutej doslovnej interpretácii Písma (napr. až korpuskulárnu teóriu aplikovanú na šest' dní stvorenia - Thierry zo Chartres).

Učebnica je cenná už z hl'adiska svojho metodického členenia. Pri každom autorovi delí jeho myšlienkovú líniu na dôležité záchytné body/kapitoly, čím pomáha čitatel'ovi napredovat' naprieč galériou stredovekého filozofického myslenia a postupne obohacovat' svoje poznatky v nadväznosti na tie predošlé.

Dôležité na tejto učebnici je aj kompletizovanie zdrojov a prekladovej literatúry na konci publikácie i priebežne po jednotlivých kapitolách. Dielo tak mapuje dôležitú domácu i cudzojazyčnú odbornú literatúru, ku ktorej sa dnes dá bežne dostat' a v prípade záujmu či potreby je možné po nej siahnut'. Dielo tak získava punc systematickosti a ponúka študentovi dôležité impulzy k hlbšiemu výskumu.

Chabada predkladá filozoficky náročné učivo stredovekej filozofie v rámci svojej vysokoškolskej učebnice didakticky korektne a metodicky správne, s postupným odhal'ovaním problematiky kvôli lepšej orientácii a navyše systematicky správnym spôsobom, ktorý robí z tejto učebnice nádejnú publikáciu s potenciálnym úspechom v radoch filozofiu študujúcich študentov i širšej odbornej verejnosti. Preto ju vrelo odporúčam čitatel'om i prípadným študentom. 


\section{Literatúra}

NEMEC, R. (2015): Chabada, M.: Kapitoly z dejín stredovekej filozofie I. Krest'anstvo a starovek. In: Filozofia, 70 (5), 404-407.

doc. PhDr. Rastislav Nemec, PhD.

Katedra krest'anskej filozofie

Teologická fakulta Trnavskej univerzity

Kostolná 1

P.O. BOX 173

81499 Bratislava

Slovenská republika

rastislav.nemec@truni.sk 